Saeculum Christianum

vol. XXII (2015)

pp. $113-135$

\author{
DARIUSZ MILEWSKI* \\ WNHiS UKSW, Warszawa
}

\title{
GOOD NEIGHBORHOOD CONFIRMED BY AN INDIGENATE - THREE CASES OF MOLDAVIAN HOSPODARS IN THE 17TH CENTURY
}

Three hospodars were particularly visible history of the Polish-Moldavian relations in the 17th century. Those were: Miron Barnovski, known also as Miron Barnovschi Movilă (16261629, 1633), Vasile Lupu (1634-1653) and Gheorghe Stefan (1653-1658). They had two things in common: the first one was that two subsequent ones ascended the throne at the expense of their predecessor - although Vasile Lupu was not the direct successor of Miron Barnovski, but he greatly contributed to his downfall - the second one was the possession of the Polish indigenate. All of them were achieved Polish nobility due to the services rendered to the Commonwealth of Poland but each of them at some stage of their career was in conflict with Poland. Their complicated fate and the meanders of their policy towards their northern neighbour perfectly reflect the character of the Polish-Moldavian relations in the turbulent 17th century. The present article shall present the figures of the indicated hospodars, with special focus on the ways in which they obtained the Polish indigenate and mechanisms that determined the policy of Moldavia, squeezed between the powerful Commonwealth and the Ottoman Empire'.

Moldavia started to be associated with Poland through ties of fief dependence at the end of the 14th century. The first homage was paid to the Polish royal couple, Jadwiga and Władysław Jagiełło by the hospodar Petru I Muşat (Piotr I Muszatowicz) on 26 September 1387 in Lviv². The indicated event coincided with regaining of the Red Ruthenia (Ruś Czerwona) by Poland from the Hungarian hands and expressed the Moldavia's search for an ally and a guardian

\footnotetext{
* Translated by Spektra Sp. z o.o.

1 Historians, mainly from Poland and Romania, are still researching this interesting subject. Each of the listed hospodars has its own Romanian biography, but these publications do not always cover all aspects of MoldavianPolish relations. Among the main works we can point out here, inter alia: A.H. Golimaş, Un domnitor - O epocă. Vremea lui Miron Barnovschi voievod al Moldovei, Bucureşti 1980; C. Şerban, Vasile Lupu, domn al Moldovei, Bucureşti 1991; E. Baidaus, Politica şi diplomația Moldovei în timpul domniei lui Vasile Lupu (relaţii politice cu Republica nobiliară Polonă şi Rusia Moscovită în anii 1634-1653), Chişinău 1998; I. Eremia, Relaţiile externe ale lui Vasile Lupu (1634-1653). Contribuţii la istoria diplomaţiei moldoveneşti în secolul al XVii-lea, Chişinău 1999; P. Zahariuc, Ţara Moldovei în vremea lui Gheorghe Ştefan voievod (1653-1658), Iaşi 2003, and also brief biographies of hospodars - D. Dragnev, E. Baidaus, G. Bodeanu, Domnii Ţării Moldovei: studii, Chişinău 2005, pp. 171-173 (password: Miron Barnovschi), p. 175-179 (password: Vasile Lupu), p. 179-181 (password: Gheorghe Ştefan).

2 An Act of homage: Main Archive of Historical Records in Warsaw (hereinafter: AGAD), Parchment Document Collection, sygn. 5334 .
} 
of Hungary. The motives that made the then hospodar to pay homage to the kings of Poland determined the future over one-hundred-year-old character of the Polish-Moldavian relations. The weaker Moldavia sought protection in Poland against Hungary but did not hesitate to join Hungary against Poland if its interests required that. A typical example of the indicated type of action was obtaining the Hungarian aid by the hospodar Stephen the Great during the trip to Moldavia of John Albert (Jan Olbracht) in 1497, which was the main reason why the Polish King abandoned the military action and retreated to Poland ${ }^{3}$. As we know, the event is regarded as a symbolic end of the Polish sovereignty over Moldavia.

One of the consequences of the Polish failure in 1497 was also associated with the first Turkish invasions, which occurred in Poland in spring and late autumn of the following year ${ }^{4}$. Those in turn were connected with the Ottoman Empire joining the competition for influence on the Danube River The victorious Mehmed II forced Moldavia as early as in 1456 to pay him a tribute and the country started to navigate between the tree neighbouring powers, winning their rivalry quite effectively. For example, it is enough to say that during the aforementioned trip of John Albert the Moldavians were also supported by the Turks who with the consent of the hospodar crossed his country and later moved on to Poland. It did not prevent Stephen the Great from attacking and crushing the Turks decimated by the frost in January 1499, when they were returning from Poland. A clever hospodar gained popularity among the Hungarians and threw away the odium of cooperation with Muslims against Christians.

Of course, the game could not be played endlessly and when after 1526 and the defeat at Mohacz, Hungary was eliminated from the group of Central European powers, Turkey used the Polish-Moldavian wars to impose direct and exclusive sovereignty on Moldavia. It occurred as a result of the military intervention of Sultan Suleiman the Magnificent (Sulejman Wspaniały) in 1538. The Hospodar Petru Rareș (Piotr Raresz), who waged another, completely unnecessary war against Poland, asked his northern neighbour for help against the Ottomans which was done too late and in vain. The king Sigismund the Old (Zygmunt Stary) did not intend to wage war against the Sultan, who dethroned the too independent hospodars and deprived Moldavia of a part of the territory, the so-called Budjak, where the Tatars settled as guardians of loyalty to Moldavian hospodars ${ }^{5}$. Then Moldavia got into the Ottoman's yoke, which was expressed both in the ever-increasing amount of the forced tribute and in the increasingly unceremonious interference of the sultans in the succession to the throne in Iași. In the second half of the 16th century the candidates for power in Moldavia began to buy Turkish nominations, offering generous bribes to the sultan or the great vizier and promising to increase the amount of the paid tribute ${ }^{6}$. Then the Turks stopped paying attention to - legal or only presumed - origin of the candidates from the Muşat family. As a result of the deepening of the indicated process, almost anyone who managed to win the favour of the Sublime Porte could become a Moldavia hospodar in the 17th century.

I. Czamańska, Mołdawia i Wołoszczyzna wobec Polski, Węgier i Turcji w XIV i XV wieku, Poznań 1996, p. 170; M. Plewczyński, Wojny Jagiellonów z wschodnimi i południowymi sąsiadami Królestwa Polskiego w XV wieku, Siedlce 2002, pp. 140-142.

4 M. Plewczyński, Wojny Jagiellonów..., pp. 153-161.

5 M. Plewczyński, Wojny i wojskowość polska w XVI wieku. Tom I. Lata 1500-1548, Zabrze 2011, pp. 394-400.

6 The first to do so was John the Terrible, called in Poland Iwonia, who was elected a Moldavian hospodar by the Turks in 1572 . 
However, the growth of the Turkish influence in Moldavia did not mean that Poland withdrew completely from the competition for the aforementioned territory. After 1538, two hospodars - Aleksander Lăpuşneanu and his son, Bohdan, paid homage to King Sigismund Augustus (in the years 1552 and 1569). Although they did not entail the submission of Moldavia to Poland, they were an expression of political preferences of both hospodars and translated into close cooperation. Bohdan lost power because of that as he was accused of too close contacts with Poland and the fact that he was surrounded by Poles made the Ottomans to use it as an argument to dethrone the hospodar in 1572. The failure of the Polish military expedition and the eminent death of Sigismund Augustus forced Poland to withdraw from the struggle to maintain its 'own' hospodar in Iași'.

The Ottoman-Habsburg War, which broke in 1593 and continued for 13 years, became an opportunity for the Commonwealth of Poland to regain its lost influence in Moldavia. The Christian vassals of the Sultan - Transylvania, Wallachia and Moldavia - found themselves in the camp of opponents, and when in 1595, Moldavia was threatened by a retaliatory Tatar invasion the Poles got involved in the matter. The Lord Chancellor and the Grand Hetman of the Crown, Jan Zamoyski, entered Moldavia at that time and placed the boyar, Ieremia Movilă, on the throne. He could prove distant affinity with the Muşat dynasty but - which was more important to Jan Zamoyski - he belonged to a group of Polonophiles who, because of their views, had to emigrate to Poland and managed to receive the Polish indigenate $^{8}$. Thanks to the diplomatic skills of Jan Zamoyski it was possible to obtain the Turkish confirmation for the authority of Ieremia Movilă and his descendants in 1595 being simultaneously the fiefs of the Sultan and the Polish king, which brought over twenty years of the Turkish-Polish condominium in Moldavia ${ }^{9}$. Gradual deterioration of the relations between the Commonwealth and the Sublime Porte led to new battles for Moldavia and ended the period of Polish influence - it was confirmed by the treaty, concluded by the Field

7 D. Milewski, Walka o tron mołdawski w 1572 roku, in: z dziejów wojskowości staropolskiej. Epoka staropolska, czasy zaborów, czasy najnowsze, ed. D. Milewski, Kraków 2011, pp. 27-47; M. Plewczyński, Wojny i wojskowość polska..., vol. 2, Lata 1548-1575, Zabrze-Tarnowskie Góry 2012, pp. 280-288.

8 It happened in 1593. The Indigenate was also granted to Łukasz Stroicz (Luca Stroici), who, in 1593, was considered as a candidate for power in Moldavia as well. To read more about indigenates see: Konstytucja „Indigenatus panów wołoskich", in: Volumina Legum (hereinafter: VL), ed. J. Ohryzko, vol. 2, Санкт-Петербур 1859, p. 345; Album armorum nobilium Regni Poloniae XV-XVIII saec. Herby nobilitacji i indygenatów XV-XVIII $w$., introduction, elaboration and edition, B. Trelińska, Lublin 2001 (dalej: B. Trelińska, Album armorum ...), nr 583, p. 250 (Jeremi Mohyła) and No. 590, p. 252 (Łukasz Stroicz) and I. Czamańska, Rumuńska imigracja polityczna w Polsce XVII wieku, „Balcanica Posnaniensia. Acta et studia”, 1993, vol. 6, pp. 7-8.

9 There is a substantive literature illustrating the Polish intervention in Moldavia in 1595. Let us mention a few works from among the many works, especially the recent ones: J. Sas, Wyprawa zamoyskiego na Moldawię, „Przegląd Powszechny”, 1897, R. 14, vol. 66, pp. 74-89 (the first scientific study of the campaign in the Polish historiography); D. Skorupa, Stosunki polsko-tatarskie 1595-1623, Warszawa 2004, pp. 59-66; P. Gawron, Jan Zamoyski, kanclerz i hetman wielki koronny, wobec zmagań turecko-habsburskich w latach 1593-1605/6, in: Polska wobec wielkich konfliktów w Europie nowożytnej. z dziejów dyplomacji i stosunków międzynarodowych w XV-XVIII wieku, ed. R. Skowron, Kraków 2009, pp. 32-36; D. Milewski, A Campaign of the Great Hetman Jan Zamoyski in Moldavia (1595). Part I. Politico-diplomatic and military preliminaries, „Analele ştiinţifice de Istorie, codrul cosminului", 2012, vol. 18, No. 2, pp. 261-286, Part II. The Battle of Ţuţora and Aftermath, ibid., 2013, vol. 19, No. 1, pp. 57-76; M. Plewczyński, Wojny i wojskowość polska ..., vol. 3, Lata 1576-1599, Zabrze-Tarnowskie Góry 2013, pp. 295-304. To read more on the conditions of the Polish-Turkish sovereignty over Moldavia see: Polski dokument porozumienia pod Cecorą, 22 X 1595 r., in: Ottoman-Polish Diplomatic Relations (15th-18th Century). An Annotated Edition of Ahdnames and Other Documents, ed. D. Kołodziejczyk, Leiden-Boston-Köln 2000 (hereinafter: D. Kołodziejczyk, Ottoman-Polish Diplomatic Relations...), No. 26, pp. 300-301 and 'Ahdname sułtana Mehmeda III dla króla Zygmunta III, Stambuł, 4 VIII 1598 r., ibid., No. 28, pp. 322. 
Hetman of the Crown, Stanisław Żółkiewski, in 1617 near Busza (Bose) when, in view of the simultaneous war with Moscow, the conflict with the Ottomans had to be avoided at all $\operatorname{costs}^{10}$. Nevertheless, the Poles ensured that the Turks appointed hospodars who were friendly to the commonwealth of Poland, as confirmed by the Treaty of Chocim (Khotyn) of $1621^{11}$. The fact that it was not only a dead letter was confirmed in 1623 when the hospodar Stefan Tomşa II was removed by the Turks at the explicit Polish request ${ }^{12}$. It was then that Radu Mihnea, the protector and direct predecessor of Miron Barnovski, accepted by the Poles, came to power. The indicated person of the hospodar was connected with the last attempt of Poland to restore the real influence in Moldavia in the Movilă spirit.

Miron Barnovski ascended the throne in Moldavia in 1626 after the death of the hospodar, Radu Mihnea. He had already had a strong position in the country at that time - he held the office of hetman and was widely regarded as the second person in the country after the hospodar. His past relations with the Poles were not too good, not to say, they were even hostile. The new hospodar was a friend of the leader of the Nogai Horde, Cantemir, and provided contributions to Ottomans in the battle at Khotyn in 1621. Therefore, he was regarded by the Turks as 'their' hospodar, while the Poles looked at him suspiciously. That is why he was easily approved to the throne in Moldavia, even though he took power in the manner which was not in line with the accepted standards. He was not appointed as a hospodar by the sultan, but was elected by the boyars after the unexpected death of Radu Mihnea. Taking advantage of his kinship with the Movilăs, he started to sign as Miron Barnovschi Movilă and called himself a hereditary Moldavian hospodar. Thus, he started strengthening his position in the country and making Moldavia itself stronger in international politics.

The ambitions of the hospodar quickly led him to an agreement with Poland. There was no other choice in the balance of power that Moldavia was in at that time. The neighbouring Transylvania was ruled by Gabor Bethlen, an enemy of Poland and a Turkish supporter, the Wallachian region's ruler was the son of Radu Mihnea, Alexandru Coconul, whereas the Crimea was ruled by Khan Mehmed III Gerej, who in 1626 organised Tatar invasions on Poland $^{13}$. None of the neighbours was suitable as an ally against the Ottomans. Therefore, if Miron Barnovski (Miron Barnovschi Movilă) decided to give Moldavia more freedom, or perhaps even to make it completely independent from Turkey, he had to make an agreement with Poland.

The events of the coming years gave him an opportunity to win the gratitude of the Poles and to enter into closer relations with them. The hospodar married a Polish woman, rejecting the hand of Radu Mihnea's daughter, which was the first sign of distancing from the Turkish

\footnotetext{
10 The Polish document on the agreement of Busza (Jaruga), 23 IX 1617, in: D. Kołodziejczyk, Ottoman-Polish Diplomatic Relations..., No. 31, pp. 345-347 and Ottoman document on the agreement of Busza, 23 IX 1617, ibid., No. 32, pp. 349-353 (with English translation).

11 The Polish document concerning the Peace Treaty of Khotyn, 9 X 1621, in: D. Kołodziejczyk, Ottoman-Polish Diplomatic Relations..., No. 35, p. 378.

12 The record of Krzysztof Serebkowicz, Warszawa, 14 III 1624, AGAD, Metryka Koronna, Libri Legationum (hereinafter: MK, LL) 30, k. 43-46; print: Documente privitoare la istoria României culese din arhivele polone, vol. 2, Secolul al XVii-lea, ed. I. Corfus, Bucureşti 1983 (hereinafter: I. Corfus, Documente...), No. 52, pp. 108-110.

13 M. Horn, Chronologia i zasięg najazdów tatarskich na ziemie Rzeczypospolitej Polskiej w latach 1600-1647, „Studia i Materiały do Historii Wojskowości” (hereinafter: SMHW), 1962, vol. 8, cz. 1, pp. 47-51.
} 
option $^{14}$. In 1627, he faced a serious international crisis. The Turks decided to build two castles at the mouth of the Dnieper River on the initiative of Khan and his energetic brother, kalga Szahin Giray, which were to block the road to the Black Sea for the Zaporozhsky Cossacks and protect the Ottoman estates from recurring invasions. The indicated initiative was unacceptable for the Commonwealth, which claimed its rights to the land on the Lower Dnieper River - the border in the Wild Fields (Dzikie Pola) was not actually established. There were also fears in Warsaw that the Turks and Tatars would strengthen their position at our borders and gain a base for invading Ukraine. Such close proximity to the Ottoman garrisons was also unsuitable for the Moldavian hospodar. Therefore, he took the opportunity to play a diplomatic game, which was to enable him stretch his wings and free himself from the stigma of the Ottoman puppet ${ }^{15}$.

Sublime Porte, when deciding to build the aforementioned castles, took into account the resistance of the Polish side. Therefore, the protection of the construction work was entrusted to the Tatars, the Turkish army led by Kapudan Hasan Pasha and both hospodars. Miron Barnovski went with the army to the Turkish camp and started mediation between the Turks and the Poles in order to alleviate the growing conflict ${ }^{16}$.

The circumstances were favourable to the hospodar's plans. Neither the Turks nor the Poles were interested in bringing about the war. The Ottoman Empire was at that time fighting against Persia, whereas the Commonwealth was struggling with the Swedes, who for the second year, under the command of Gustavus Adolfus, remained in the Royal Prussia. The Field Crown Hetman Stanisław Koniecpolski was on the Prussian front, whereas Stefan Chmielecki, a regimentarz (a military commander) left in Ukraine with a small group of soldiers was not strong enough to attack the Turks. Of course, it did not mean that he did not threaten them, especially using a Cossack bogey - but also the Tatars, on the other hand, rushed to Ukraine, sniffing around the opportunity to take captives and gather loot. However, both commanders - Stefan Chmielecki and Hasan Pasha - had to think about the consequences of a possible feud and the lack of preparation of their countries for war. So, they tried to scare each other off. They 'got help' in this respect from the Moldavia hospodar.

Enjoying the trust of the Turks at that time, Miron Barnovski launched a mediative initiative against the Poles ${ }^{17}$. It was accepted with mistrust but, on the other hand, there was no sensible alternative. Therefore, Captain Baltazar Witkowski was sent to the Turkish camp to investigate the matter and put the Polish veto on the Turkish plans. The Polish messenger received support from the hospodar who mediated in the talks. Baltazar Witkowski made therefore an encouraging report to Stefan Chmielecki, after which another messenger, Aleksander Chocimirski, who had already received royal instructions, was sent. Both sides came to an agreement then: The Turks were content to repair the walls of Ochakiv, the Tatars

\footnotetext{
14 The identity of Miron Barnowski's Polish wife remains controversial among historians. For more information on this subject see, inter alia: A.H. Golimaş, Un domnitor - O epocă..., p. 30; N. Stoicescu, Dicţionar al marilor dregători din Ţara Românească şi Moldova, sec. XIV-XVII, Bucureşti 1971, p. 344, password: Barnovschi (Movilă) Miron; V. Constantinov, Alianţe dinastice în Ţara Moldova după domniile lui Radu Mihnea, ,, Revista de Istorie a Moldovei", 2008, No. 2 (74), p. 69.

15 B. Baranowski, Polska a Tatarszczyzna w latach 1624-1629, Łódzkie Towarzystwo Naukowe, Wydział II, Sectio II, No. 1, Łódź 1948, pp. 67-68.

16 Murad IV do Mirona Barnowskiego, maj 1627 r., in: Documente privitóre la istoria Românilor urmare la colecţiunea lui Eudoxiu Hurmuzaki, supl. 2, vol. 2, ed. I. Bogdan, Bucuresci 1895, nr CCXLIII, pp. 537-538.

17 Miron Barnowski do S. Chmieleckiego, obóz pod Tehinią, 4 VII 1627 r., ibid., No. CCXLIV, p. 539.
} 
restored the old castle of Aslan Kerman, whereas the Poles undertook to stop the Cossacks from expeditions to the Black Sea. The guarantor of the agreement was the hospodar, Miron Barnovski ${ }^{18}$.

The hospodar succeeded in sending a Polish bishop, Jerzy Kruszyński, to Istanbul, in spring the following year and renewed the conditions of peace with the Ottomans ${ }^{19}$. Then Miron Barnovski reached the peak of success and recognition on both sides. Unfortunately, further development of the situation forced him to show his intentions and take a clear stand on the side of Poland.

The Cossacks, who disregarded all agreements, attacked the Turkish Black Sea estates in 1628. It aroused suspicion among the Turks about the honesty of the hospodar, who in the meantime futilely sought the support of Poles to stop the Cossacks. What was worse, however, was launching a civil war among the Tatars. Kalga Shahin Giray attacked Cantemir and was unexpectedly defeated. Cantemir obtained Port's consent to oust the rebellious Giray brothers from power and together with his army went to Crimea where he besieged Khan Mehmed III Giray in Bakhchisarai. Shahin Giray managed to communicate with the Cossacks, who, under the command of Michał Doroszenko entered the Crimea, defeated Cantemir and even besieged him in the Turkish Kaffa ${ }^{20}$.

In this situation, the Turks undertook a military intervention on the side of Cantemir, and ordered the hospodars to come with help. Miron Barnovski found himself in an awkward position because the Poles, in turn, silently endorsed the Cossacks. He therefore sent symbolic reinforcements to the Turks and he himself urged the Poles to support Shahin Giray. Kalga himself, in view of the Turkish advantage and the Cossacks' unwillingness to continue fighting, had to withdraw to Ukraine with his brother. The Turks wanted both brothers to be turned in by the Poles. However, both the king and Stefan Chmielecki pretended not to know where Mehmed and Shahin Giray might be. Meanwhile, they were preparing a new Cossack expedition, which was to restore power to the brothers. The autumn campaign of 1628 was a failure but in spring 1629 a large Cossack expedition to Crimea started. The hospodar did not support the Turks and the new Khan, Janibek II Giray at that time. He did not even provide the support to the Cossacks. Unfortunately, the expedition ended in defeat and the death of Khan Mehmed III Giray, while the Turks discovered that Moldavians were in the hostile army. In Istanbul, a decision was made to dethrone the hospodar ${ }^{21}$.

\footnotetext{
18 The report on the talks conducted with the Turks by B. Witkowski, in the camp over Suria, autumn, 1627, Biblioteka Jagiellońska, rkps 211, k. 463-464v, 473-474 continuation; the report of Aleksander Chocimirski from the mission to Hasan Pasha, 14 IX 1627, ibid., k. 417-419v.; Hasan Pasza to S. Chmielecki, near Oczaków, ca. 14/24 IX 1627,ibid., k. 421-421v.

19 Murad IV to Sigismund III, Istambul, 6-15 IV 1628, in: Katalog dokumentów tureckich. Dokumenty do dziejów Polski i krajów ościennych w latach 1455-1672, ed. And elab. Z. Abrahamowicz, in: Katalog rękopisów orientalnych ze zbiorów polskich, ed. S. Strelcyn, vol. 1, part 1, Warszawa 1959, No. 264, p. 256.

20 M. Berindei, La Porte Ottomane face aux Cosaques zaporogues. 1600-1637, „Harvard Ukrainian Studies”, 1977, vol. 1, z. 3, pp. 299-301.

${ }^{21}$ The civil wars in the Crimea in the years 1628-1629 and the participation of the Cossacks in them are described by, among others: B. Baranowski, Polska a Tatarszczyzna..., pp. 78-99 and М. Грушевський, Історія УкраӥниPycu, vol. 8, Нью-Йорк 1956, pp. 41-43. See also Relacja o nieprzyjaźni między Dżanibeg Girajem i Muhammed Girajem i Szahin Girajem, carami prekopskimi, w: Ukrainne sprawy. Przyczynek do dziejów polskich, tatarskich i tureckich XVII wieku ed. S. Przyłęcki, Lwów 1842, pp. 1-10. To read more on the subject of the dethronat ion of Miron Barnovski because of his suport for Shahin Giray, see: Ph. de Harley, hr. de Césy do Ludwika XIII, Pera,
} 
The Ottomans were helped in making such a decision by the fact that Miron Barnovski was closely connected with Poland and that he accepted the indigenate. The hospodar undertook efforts to obtain the indicated privilege as early as in 1628 when he still enjoyed the recognition of the Turks. He gained support of the main diets (sejmiki), and also the Sieradz Castellan himself, Maksymilian Przerębski, the husband of Anna Movilă (Mohylanka). The indicated senator decided to accept the hospodar under his coat, Nowina. The case was submitted to the extraordinary Sejm in summer 1628. Unfortunately, King Sigismund III decided to deal with the financial matters at the Sejm, postponing all other issues. Therefore, despite the requests of the Moldavian legation and the support of deputies, no resolution on granting the Polish indigenate to Miron Barnovski was made. However, a diploma was issued and he entered the books of the Royal Register (Metrica Regni Poloniae), and a promise was made to settle the matter at the nearest $\mathrm{Sejm}^{22}$.

In fact, it happened in winter, 1629, at the Ordinary Sejm in Warsaw. The hospodar, having again gained the favour of some sejmiks (diets), managed to achieve his goal. The Sejm passed a resolution on awarding indigenate to Miron Barnovski, and the diploma was again entered in the Royal Register ${ }^{23}$. The original diploma was delivered to the hospodar in spring 1629 by the bishop of Bakovo, Mikołaj Fredro ${ }^{24}$. Another royal messenger, Teofil Szemberg, took an oath of allegiance to the Polish king from Miron Barnovski ${ }^{25}$. In this way, the hospodar became a Polish nobleman and at the same time a vassal. Both sides could be satisfied with this state of affairs. Miron Barnovski, already a Polish nobleman, bought extensive estates from Maksymilian Przerębski in - an inheritance from Movilăs- due to which he gained an anchorage in the Commonwealth ${ }^{26}$. Poland, in turn, gained a vassal in him and expected the rebuilding of its influence in Moldavia from the times of the Movilă dynasty.

Unfortunately, the promising future was soon crossed out. The failure of the Cossack expedition to Crimea in June 1629 and the Turkish decision to dethrone Miron Barnovski, made a month later, destroyed his and Polish efforts to free Moldavia from strict Ottoman control. For a long time now, Gabor Bethlen, a man who hated the hospodar, had been plotting against him and worked on assembling an anti-Polish coalition with the involvement of Turkey and Moscow ${ }^{27}$. The Duke of Transylvania planned to replace Miron Barnovski with Moses Movilă. However, Alexandru Coconul, a former Wallachian hospodar who dreamt

8 VII 1629 r., in: Documente privitóre la istoria Românilor urmare la colecţiunea lui Eudoxiu Hurmuzaki, supl. 1, vol. 1, ed. G.G. Tocilescu, A.I. Odobescu, Bucuresci 1886, No. CCCXXXIV, p. 230.

22 Przywilej indygenatu dla Mirona Barnowskiego, Warszawa, 20 VII 1628 r., AGAD, MK 177, k. 15-16v.

23 Konstytucja „Indygenat hospodara wołoskiego”, VL, vol. 3, Санкт-Петербур 1859, p. 295; Przywilej indygenatu dla Mirona Barnowskiego, Warszawa, 20 II 1629 r., AGAD, MK 177, k. 213-215b. To read more on the topic see: D. Milewski, The Granting of Polish indygenat to the Moldavian Voyevode Miron Barnovski, „Medieval and Early Modern Studies for Central and Eastern Europe", 2011, vol. 3, pp. 117-149.

24 M.G. Fredro do Zygmunta III, Jassy, po 15 IV 1629 r., Biblioteka Muzeum Narodowego im. Książąt Czartoryskich w Krakowie, rkps 357, pp. 1077-1078.

25 The text of the oath taken by Miron Barnovski, Jassy, bdm, 1629, in: I. Corfus, Documente..., No. 67, pp. 126-127. ovski

26 W. Łoziński, Prawem i lewem, Obyczaje na Czerwonej Rusi w pierwszej połowie XVII wieku, elab. J. Tazbir, Warszawa 2005, pp. 394-395.

27 M. Cichocki, Mediacja Francji w rozejmie altmarskim, „Rozprawy Polskiej Akademii Umiejętności. Wydział Historyczno-Filozoficzny. Series II, vol. XLII”, Kraków 1930, pp. 148-151. 
of returning to power, forestalled him. Thanks to generous bribes, he was granted a Turkish nomination for a Moldavian hospodarship ${ }^{28}$.

The drama of Miron Barnovski took place in summer and autumn 1629. Poland, which was finalising peace talks with Sweden, could not offer him a real help. Meanwhile, upon hearing the news of dethroning, the boyars who betrayed the hospodar started a rebellion and won the army over to their side ${ }^{29}$. The leaders were: the Great Chancellor (Wielki Logofet) Dumitraşco Ştefan, the panthler (stolnik) Grama and the Grand Treasurer (wielki wisternik) Lupu Coci - the future hospodar Vasile Lupu. When in late summer 1629, Alexandru Coconul, led by the Turks and Tatars, finally seized power in Iași, it was Lupu Coci who led the expedition against the former hospodar. Miron Barnovski took refuge with a small army and supporters in the Khotyn Castle, over the Polish border. Lupu Coci defeated the army of Miron Barnovski but he could not conquer the strongly armed fortress. The Poles, who were engaged in repulsing the Tatar invasion, did not help Miron Barnovski, so at the beginning of 1630 , he had to finally leave the territory of Moldavia and settle in his estates in Ruthenia ${ }^{30}$.

Being in exile in Poland, Miron Barnovski planned to return to Moldavia. Misgovernance of Alexandru Coconul was terminated by the Turks themselves in 1630 by appointing Moses Movilă to his place, whose successor became Alexandru Iliaș in 1631. The strength of Lupu Coci grew with new hospodars, and all kinds of foreigners, mainly Greeks, who surrounded both Alexanders. The Moldavians did not like it and in 1633, they rebelled against the hospodar and called for a return of Miron Barnovski. He did not fail to take the opportunity to return to Iași. In order to obtain the Turkish approval this time, he agreed to visit Istanbul personally ${ }^{31}$. There, however, the intrigues of his enemies, with irreplaceable Lupu Coci, quickly led to the imprisonment and execution of Miron Barnovski. It happened at the beginning of July 1633. He was again replaced on the Moldavian throne by Moses Movilă $^{32}$. However, the aforementioned ruler quickly ran afoul of the Turks by supporting the Poles in their frictions with beylerbey (commander-of-commanders) Otchakiv Abaza Pasha in the years 1633-1634. The Polish-Turkish war almost started at that time, however, the information on defeating Russians near Smolensk by Ladislaus IV, the conclusion of the Polish-Moscow peace treaty and the commencement of the expedition of the Polish army

28 C. Haga do Gabora Bethlena, Pera, 13 VI 1629 r., in: Török-Magyarkori történelmi emlékek: Okmánytár, vol. 4, ed. Á. Szilády, S. Szilágyi, Pest 1869, No. XIX, p. 111; J. Donátt do Gabriela Bethlena, Stambuł, 19 VII 1629 r., ibid., No. XXVI, pp. 123-124.

29 S. Chmielecki do Zygmunta III, Kamieniec Podolski, 17 VII 1629 r., Львівська наукова бібліотека ім. В. Стефаника НАН України, fond 103, Sapiehowie, ch. 1, file 7, No. 1046; Miron Barnowski do bractwa stauropigialnego we Lwowie, Chocim, 21 VII 1629 r., Центральний державний історичний архів України, м. Львів (dalej: ЦДІАУ), fond 129, op. 1, spr. 505.

30 G. Duzinchevici, Miron Barnovschi Moghilă şi Polonii, „Anuarul Institului de Istorie Naţională”, red. A. Lapedatu, I. Lupaş, vol. 7, 1936-1938, Bucureşti 1939, pp. 186-188; A.H. Golimaş, Un domnitor - O epocă..., pp. 97-109 .

31 Miron Barnowski do S. Koniecpolskiego, Ruszczuk, 22 V 1633 r., AGAD, MK, LL 32, k. 91-92; print: Korespondencja Stanisława Koniecpolskiego, hetmana wielkiego koronnego 1632-1646, elab. A. Biedrzycka, Kraków 2005 (hereinafter: A. Biedrzycka, Korespondencja...), No. 21, pp. 116-117.

32 The short reign of the Moldavian hospodars in the years 1629-1633 are described by M. Costin, Latopis ziemi mołdawskiej, in: idem, Latopis ziemi mołdawskiej i inne utwory historyczne, ed. I. Czamańska, Poznań 1998, pp. 155-163. To read more on the murder of MironBarnovski and his successor Moses Movilă see:. C. Haga do stanów, Stambuł, 12 VII 1633 r., in: Studii şi documente cu privire la istoria Romînilor, vol. 4: Legăturile principatelor romîne cu Ardealul de la 1601 la 1699, ed. N. Iorga, Bucureşti 1902, No. XLVIII, pp. 200-202. See also: I. Eremia, Relatiile externe..., pp. 41-47. 
towards the territories near the Dniester River ${ }^{33}$ made Sultan Murad IV refrain from it. The Turks withdrew from the already announced war, killed its main spokesman, Abaza Pasha, and changed the hospodar of Moldavia as well. They preferred to have 'their own' man there. Lupu Coci, plotting against Moses Movilă, was chosen. The new hospodar started his reign under the name of Vasile Lupu.

The change was unfavourable for the Poles again. Vasile Lupu came to power, after he had dethroned the hospodar who was favourable to Poland. He himself came from deep Balkans - probably from the Arumunian population living in the Rhodopes-and he had no fondness for Poland. He was not attached to Moldavia either, where he came together with the hospodar, Radu Mihnea ${ }^{34}$. In contrast to Miron Barnovski, Vasile Lupu was one of the foreign boyars, treating Moldavia as a convenient place to make a personal career. It was therefore difficult to expect that he would like to liberate the country from the Ottoman power and would bind himself to Poland for the indicated purpose. He was rather expected to be a faithful executor of the Ottoman policy. However, even he - as was to turn out - did not avoid this kind of 'destiny' of ambitious Moldavian rulers.

The path of Vasile Lupu to an agreement with the Commonwealth and obtaining the polish indigenate was long - especially when we compare it with the one of Miron Barnovski. The Moldavian hospodar tried to obtain the Polish indigenate as late as in 1650 and he received it. He had already occupied the throne in Iași uninterruptedly for 16 years, which was quite a feat and proved Vasile Lupu's proficiency in the difficult art of politics. He undoubtedly learned from the mistakes made by his predecessors and avoided open involvement in matters which might worsen his position in the eyes of the sultan. However, he also benefited from the international situation and the priority adopted by him to build his own position rather than fight for the independence of Moldavia.

The last serious Polish-Turkish crisis ended amicably in 1634, on the threshold of the reign of Vasile Lupu. From that moment nothing serious undermined the relationship between the Commonwealth and Turkey during the following ten years. The Cossack attacks were significantly reduced by building the Kodak fortress and defeating the uprisings of Pawluk, Ostrzanin and Hulanica in the years 1637-1638. There were no major Tatar invasions on Ukraine, either ${ }^{35}$. In the indicated situation, Vasile Lupu limited himself to maintaining proper relations with Poland and correspondence with the Great Crown Hetman Stanisław Koniecpolski. His mediator was at that time the Polish secretary, Jerzy Kutnarski, who at the end of the regnal period of Vasile Lupu became very important ${ }^{36}$. The attention of the

\footnotetext{
33 The Polish-Turkish disputed has been elaborated on in: L. Podhorodecki, Wojna polsko-turecka 1633-1634, SMHW, 1976, vol. 20, pp. 27-72.

34 N. Stoicescu, Dicţionar al marilor dregători..., pp. 377-378, hasło: Coci Lupu; C. Şerban, Vasile Lupu..., p. 2226; V. Constantinov, Ţara Românească şi Ţara Moldovei în timpul domniilor lui Radu Mihnea, Iaşi 2007, p. 150 .

35 During the period in question, the Tatars organised only two large expeditions: in winter 1640 and in summer 1643 - See: M. Horn, Chronologia i zasięg..., pp. 61-63. To read more on the Cossack uprisings in the years 1637-1638 See: W. Tomkiewicz, Bitwa pod Kumejkami (16 Xii 1637), „Przegląd Historyczno-Wojskowy”, 1937, ol. 9, file. 2, pp. 239-261 and the latest monographs: M. Gawęda, Powstanie kozackie 1637, Zabrze 2007 and A. Borowiak, Powstanie kozackie 1638, Zabrze 2010.

36 For example, in 1637, Vasile Lupu informed the hetman via Jerzy Kutnarski n domestic battles amongst the Tatars, and in autumn of that year about the end of the war with Wallachia - see: Bazyli Lupul do S. Koniecpolskiego, bm., druga połowa lutego 1637 r., in: A. Biedrzycka, Korespondencja..., No. 226, pp. 348-350; id.to idem, Jassy,
} 
hospodar was sometimes drawn to minor border fights, always numerous ${ }^{37}$. Meanwhile, however, the hospodar focused his energy on the rivalry with the Wallachian neighbour, Matei Basarab, whom he tried to deprive of power in the 30s of the seventeenth century and replace him with someone from his own family. Moreover, he did not hesitate to make fief deals with the Duke of Transylvania, George I Rákóczi, to strengthen his position in the game on the Danube River. Let us add that the Duke of Transylvania made similar arrangements with the Wallachian hospodar and, in turn, he grew in importance among his rival neighbours. Thanks to this skillful policy, Transylvania gradually regained the influence in the Danube principality that was once had by the Kingdom of Hungary ${ }^{38}$.

Summing up - during the first regnal years of Vasile Lupu, Poland was not very important to the ruler. Hence, he did not strive for a Polish indigenate. The situation started to change in 1644. One of the first signs of warming in the Polish-Moldavian relations was the hospodar's consent to bring Jesuits to Moldavia. The indicated matter was tackled by Jerzy Kutnarski, who at the same time entered a sharp conflict with the Martian-Polish archbishop Marek Bandułowicz, residing in Moldavia and being subservient to the Pope. There was a Catholic bishop in Bakovo (Bacău) in Moldova, for whom the presence of the second hierarch was inconvenient. The bishops of Bakovo, who were Poles, neglected their diocese, rarely visiting it and only derived income from $\mathrm{it}^{39}$. This made it all the worse to see the zealous Marek Bandułowicz, who was supposed to convert the Bulgarians but resided in Moldavia for security reasons. The conflict between the king Ladislaus IV and the papal nuncio in Poland, Mario Filonardi, was additionally superimposed on it. Thanks to Jerzy Kutnarski, the hospodar decisively supported the Polish side, which could not go unnoticed in Warsaw ${ }^{40}$.

A further step on the way to closer relations between the hospodar and the Commonwealth was the marriage of his daughter, Maria Helena, to the Lithuanian Chambarlain, the duke Janusz Radziwiłł. The young Lithuanian magnate started to seek the hand of the hospodar's daughter as early as in 1643 . However, he had to overcome many obstacles along the way. Initially, the hetman Stanisław Koniecpolski did not preceive the aforementioned plans favourably and the Duke of Transylvania, George I Rákóczi totally objected it. In his own interest, he tried not to let the Polish-Moldavian relations become closer and made efforts to torpedo the marriage plans in Istanbul. Finally, however, the obstacles were overcome, the hospodar obtained the sultan's consent to his daughter's marriage and it took place in Iași on 5 February 1645. The ceremony was honoured by the messages from the Polish king, Kurland and Prussian princes, the Wallachian hospodar and the Constantinopole patriarch.

\footnotetext{
25 XI 1637 r., Ibid., No. 300, pp. 433-434. See also: D. Milewski, Jerzy Kutnarski - Polak w stużbie mołdawskiej i polskiej, „Echa Przeszłości”, 2012, vol. 13, pp. 110-111.

37 For example, in 1639, he complained to the widow of the Great Crown Chancellor about the attack of the subperfect of Raszków who kidnapped and imprisoned the perculab (castellan) of Sorock - Bazyli Lupul do Katarzyny z Ostrogskich Zamoyskiej, Jassy, 26 VI 1639 r., AGAD, Archiwum Zamoyskich, sygn. 413, pp. 10-11.

38 The Dukes of Transilvania felt like heirs of the Hungarian kings and 'inherited' from the claims to sovereignty over Moldavia and Wallachia as well.

39 In the discussed period, the bishop of Bakovo was Jan Zamoyski, a dominican.

40 To read more on the topic see: D. Milewski, Jerzy Kutnarski..., pp. 111-115.
} 
The ceremony was celebrated by the bishop of Kiev, Petru Movilă, who had already been involved in efforts to contract the marriage ${ }^{41}$.

The Moldavian marriage of Janusz Radziwiłt, the favourite of Ladislaus IV, from whom the Lithuanian Chamberlain received the promotion to the position of the field hetman in 1646, was an element of a broader political game undertaken by the Polish king. It was connected with the plans concerning the Turkish war. Ladislaus IV, who during his entire regnal time, thought about the war with the Crescent several times, became seriously interested in the indicated matter after the Polish victory over the Tatars in the battle of Ochmatów in January 1644. The Poles decided to withhold the payment of gifts to the Tatars then, and the king made efforts to convince the nobility to deal with the Muslims. An additional incentive for him was the beginning of the Turkish-Venetian war for Crete in 1645 . The indicated conflict attracted the attention and the strength of the Turks and at the same time activated the Venetian diplomacy to seek an ally. Since both Austrian and Spanish Habsburgs were involved in the Thirty Years' War, Poland could be the only real ally for Venice. In 1645, a Venetian deputy, Giovanni Tiepolo, came to Warsaw to persuade the king to join the war with the Ottomans.

A testing time for Vasile Lupu, who in the situation of the Polish-Turkish peace was calmly balancing between the two powers, began. This time, the hospodar took the side of the emerging anti-Turkish coalition at an early stage. In this case, he was supported by his recent rival, the Wallachian hospodar, Matei Basarab. Both rulers, who had been ruling in their countries for quite a long time - Matei Basarab ascended to the throne in 1632 - were sick of the role of Turkish puppets and wanted to obtain more independence. The same ambitions that had pushed Miron Barnovski into the arms of the Commonwealth less than 20 years earlier were awakened in the Moldavian hospodar. Vasile Lupu followed the same path, although - as we will see - ha was more cautious.

The hospodar started with an information campaign. In the first year of the war for Crete he started to inform both Venetians and Poles about the actions of the Turkish army, and at the same time to misinform the Ottomans on the war preparations in Poland ${ }^{42}$. In February 1646, he sent a message to Warsaw, officially to congratulate the king on the marriage to Ludwika Maria, and unofficially, to discuss the matters concerning the Alliance ${ }^{43}$, and in July of that year he hosted in Suceava his son-in-law, Janusz Radziwiłł, who visited Moldavia and Transylvania with a mission to win them over to the alliance against the Turks. The Venetian deputy in Poland was enthusiastic about the vision of an imminent war to be waged by both hospodars - their task was to maintain the Danube line until the arrival of the Polish troops there and supply them for winter ${ }^{44}$.

Unfortunately, the joy was premature and Vasile Lupu himself quickly realised that the royal plans were unrealistic. Still in the same year 1646, he started to withdraw from his

\footnotetext{
41 To read more on the marriage of Janusz Radziwiłł to Maria Helena Lupulówna see:zob. D. Milewski, Between a Magnate and a Cossack - Two Marriages of Vasile Lupu `s Daughters, „Series Byzantina”, 2008, vol. VI, pp. 47-55. Ibid. The sources and literature on the subject matter.

42 E. Baidaus, Politica şi diplomaţia..., p. 47; D. Milewski, Mołdawia w planach wojny tureckiej Władysława IV, „Przegląd Wschodni”, 2005/2006, vol. 9, file 4 (36), pp. 725-726.

43 W. Czermak, Plany wojny tureckiej Władystawa IV, Kraków 1895, p. 88; I. Eremia, Relaţille externe..., p. 168.

44 Relacja Jana Tiepola posła nadzwyczajnego Rzplitej Weneckiej do najjaśniejszego Władystawa IV, króla polskiego i szwedzkiego, r. 1647, w: zbiór pamiętników historycznych o dawnej Polscze, ed. J.U. Niemcewicz, vol. 5, Puławy 1830, pp. 22-23. To read more on the activities of Vasile Lupu in the years 1645-1646 and the mission of Janusz Radziwiłł, see: D. Milewski, Mołdawia w planach..., p. 725-731.
} 
promises given to Poland and even went so far as to send Dziebałtowski, a Polish messenger, to Istanbul in autumn that year. To evoke the impression of grandeur he added his people and numerous gifts and presented the entire mission to the Turks as his contribution to the efforts aimed at preventing the war. He gained the gratitude of the Turks and the grievances of the disappointed Polish king with the aforementioned move but nevertheless he achieved his goal: he protected himself from the accusations - justified, which must be admitted of cooperation with Poland against Turkey in a situation when there was no risk of war ${ }^{45}$.

The failure of military plans of Ladislaus IV and return to loyalty to Turkey of Vasile Lupu could lead to another breach between Poland and Moldavia. However, unexpectedly the hospodar found another opportunity to actively enter the political life of the Commonwealth and 'work out' a way to be awarded the Polish iniygenate. It occurred due to the outbreak of Cossack uprising under the command of Bohdan Khmelnytsky in 1648 and unexpected defeat of the Polish army, one of the consequences of which was the Tatar slavery of both Crown Hetmans: the Great Hetman Mikołaj Potocki and Field Hetman Marcin Kalinowski.

The civil war in the Commonwealth would not attract much of the Moldavian hospodar's attention if it had not been for the Cossack-Tatar alliance. Vasile Lupu was constantly afraid of the growing importance of the Tatars and therefore from the very beginning he took a negative attitude to the Cossack uprising. He did not limit himself to act as usual as the Polish side's informant about the actions of Cossacks, Tatars and Turks, but actively joined the actions aimed at breaking the Cossack-Tatar alliance and freeing hetmans and other Polish prisoners of war from captivity in the Crimea. The indicated activity won him the favour of the nobility and, in consequence, the Polish indigenate and on the other hand, the suspicion and reluctance of the Cossacks and Tatars.

In summer in 1648, the Moldavian hospodar joined the diplomatic game undertaken by the Grand Chancellor of the Crown, Jerzy Ossoliński, concerning Turkey. Opposing the Tatars' invasion of Poland, the Chancellor simultaneously provided the Turks with explanations on the Polish preparations made earlier, which were supposedly directed against the Cossacks. Of course, it was not true, however, the hospodar, who was asked to help deliver Polish letters to Instanbul, added a 'good advice' from himself that the Poles had just obtained an excellent reason to start a war with the Ottomans. It was to be expected that the present Cossack uprising-just like all the previous ones - would soon be suppressed and then the nobility would repay Turkey and the Tatars for providing help to Bohdan Khmelnytsky. It would be better to satisfy the Poles in advance, recall Tatars from Ukraine and order them to release the Polish prisoners of war.

The aforementioned Polish-Moldavian action was close to achieving its goal and the Turks had indeed reprimanded Tatars for their participation in war when everything changed due to the palace coup in Instanbul and the murder of sultan Ibrahim I in August 1648. Sufi Mehmed pasha, a new great vizier with a minor Mehmed IV, rightly concluded that as long

\footnotetext{
45 The matter of starting the war with Turkey was made invalid by the autumn Sejm of 1646, in Warsaw, although after the July Senate Council in Cracow, one could have expected that the royal plans would not gain the approval of the nobility. On the other hand, the royal plans were known to the Turks which Janusz Radziwiłł complained about as early as in summer, 1646, so it is no wonder, that the hospodar preferred to be careful.- See: J. Radziwiłł do J. Kiszki, Suczawa, 10 VII 1646 r.,in: E. Kotłubaj, Życie Janusza Radziwiłła, Wilno-Witebsk 1859, Dodatek IX, nr 1, pp. 337-339, and also W. Czermak, Plany wojny tureckiej..., pp. 222-241, 257-264 and D. Milewski, Mołdawia w planach..., pp. 730-736. An interesting description of the change in the hospodar's decision to terminate obedience to the Turks was left by a Moldavian chronicler.- M. Costin, Latopis ..., pp. 180-181.
} 
as the Tatars dealt with the Poles in Ukraine, it was not possible to wage the Polish-Turkish war. Therefore, he gave the horde a free hand, and wrote back to the Poles that they were to blame themselves for the situation because they did not pay due gifts to the Tatars ${ }^{46}$.

The failure of the diplomatic action did not denote the end of the Polish-Moldavian cooperation. Vasile Lupu concentrated on another task which was to buy out the crown hetmans from the Tatar captivity. The talks on the subject commenced in autumn 1648 but as a result of Bohdan Khmelnytsky 's resistance, the aim was not reached then. The period of the Zbarazh-Zboriv battle in 1649 was spent by both crown hetmans in the Crimea. However, the actual failure of the Poilsh army in 1649 and the acceptance of difficult conditions of peace with the Cossacks and the Crimea at Zboriv paradoxically facilitated the efforts to buy out the hetmans. The Tatars felt that they were the masters of the situation in Ukraine and ceased to fear the Poles. What's more, the Khan Islam III Giray began to plan a joint Tatar-Cossack-Polish attack on Moscow, which might eventually result in rebuilding of the Volga Khanates by Ivan IV the Terrible. The perspective of such an action was unrealistic, as neither the Cossack hetman, flirting with Moscow, nor the Warsaw court, where they thought rather about breaking the Cossack-Tatar alliance by undertaking old plans of war with Turkey, showed interest in it. Nevertheless, at the beginning of 1650, a warming of Polish-Tatar relations was observed, accompanied by cooling of Tatar-Cossack contacts. It finally made it possible to finalise the efforts to buy out the hetmans from the Tatar hands.

The matter was so difficult that the Tatars, having such valuable prisoners, demanded shyhigh sums, which could not be paid by the hetmans' families, as most of their property was in the hands of the Cossacks ${ }^{47}$. Therefore, money was collected very slowly, and it was impossible to collect the whole amount in time. The Moldavian hospodar was helpful again. Still in 1649, he declared his willingness to mediate in buying out the Great Hetman of the Crown, offering Iași as a place where money would be exchanged for a hostage ${ }^{48}$. After warming of Polish-Tatar relations in winter 1649/1650, the Polish side managed to negotiate the Khanate's consent to release hetmans in exchange for a part of the ransom demanded - the payment of the rest of the money was to be guaranteed by close relatives of the Polish chieftains, including the son of the Great Hetman, Mikołaj Potocki - the future, unfortunate defender of Kamianets Podilskyi in 1672. They were left as hostages in the Crimea. Meanwhile, money was paid to the Tatars, and this time the help of the Moldavian hospodar, who acted not only as an intermediary but also as a banker of the Poles, was indispensable. As may be guessed from the course of events, he put aside the money demanded by the Tatars and then recovered it from the treasury of the Commonwealth ${ }^{49}$. Thanks to that, in spring 1650, first Mikołaj Potocki, and then Marcin Kalinowski returned to Poland.

\footnotetext{
46 To read more on the Polish-Moldavian dilomatic action in Istanbul in summer, 1648, see: D. Milewski, Rywalizacja polsko-kozacka o Mołdawię w dobie powstania Bohdana Chmielnickiego (1648-1653), Zabrze 2011, pp. 45-59 .

47 The sum required for the Great Hetman amounted to 100 to 200 thousand zloty, whereas for the Field Hetman the required sum was 100 thousand red zloty - W. Majewski, Mikotaj Potocki, in: Polski stownik biograficzny, vol. 28, Warszawa 1984, p. 108; W. Czapliński, Marcin Kalinowski, ibid., vol. 11, Warszawa 1964-1965, p. 463.

48 Vasile Lupu to Ł. Miaskowski, Jassy, 21 IV (?) 1649 r., in: Documente privitóre la istoria Românilor. Urmare la colecţiunea lui Eudoxiu de Hurmuzaki, supl. 2, vol. 3, ed. I. Bogdan, București 1900, No. XIII, pp. 15-16 (the letter was erroneously dated by the publisher to 21 IX 1645); D. Milewski, Rywalizacja polsko-kozacka..., pp. 83-85.

49 To read more on the topic, see: D. Milewski, Rywalizacja polsko-kozacka ..., pp. 87-92; E. Baidaus, War, Diplomacy, and "Family Affairs" in Seventeenth-Century Eastern Europe: Moldavia in the Danubian Policy of Bohdan
} 
Such a great contribution of the Moldavian hospodar for the Commonwealth could not go unnoticed either in Warsaw or in Czehryn. Bohdan Khmelnytsky recognised Vasile Lupu as one of his main enemies, who, in addition, stood in his way to bring about a CossackTransylvanian alliance. In summer 1650, he organised a rapid and devastating Tatar and Cossack invasion of Moldavia, forcing the hospodar to pay substantial ransom together with a promise that his younger daughter, Rozanda Lupulówna, would marry the son of the Cossack hetman, Timofiy Khmelnytsky ${ }^{50}$. It was to be a prelude to the subjugation of Moldavia to the Cossack country and its surroundings from the south of Commonwealth.

In the indicated situation, Vasile Lupu finally admitted that he would need the Polish indigenate. He decided not to fulfil his matrimonial obligations towards Bohdan Khmelnytsky and become more closely associated with Poland. The Cossacks' attack on the befriended Moldavia was perceived - despite all the excuses made by Bohdan Khmelnytsky ${ }^{51}$ - as a breach of the agreement and a prelude to war. John Casimir was even ready to attack the Cossacks at once, which was discussed with the field hetman of Lithuania, Janusz Radziwiłłhowever, the son-in-law of Vasile Lupu, led the king away from the premature attack, for which the Lithuanian army had not yet been prepared ${ }^{52}$. It was decided to keep the hospodar faithful to Poland instead, offering him indigenate, which he himself had asked for through the Grand Hetman of the Crown, Mikołaj Potocki ${ }^{53}$.

Khmelnytsky(1648-1653), "Canadian Slavonic Papers / Revue canadienne des slavistes”, vol. LIV, nos. 1-2, MarchJune 2012 / mars-juin 2012, pp. 42-43.

50 A description of the invasion can be found in the account of the Moldavian chronicler who was a contemporary of the indicated events. - M. Costin, Latopis..., pp. 190-193. See also: I. Eremia, Relatiile externe..., pp. 202-210; D. Milewski, Rywalizacja polsko-kozacka..., pp. 127-137; E. Baidaus, War, Diplomacy, and “Family Affairs"”..., pp. 44-47.

51 B. Chmielnicki to M. Potocki, Jampol, 28 IX 1650 r., in: Документи Богдана Хмельницького 1648-1657, ed. І. Крип`якевич, Київ 1961, №. 117, pp. 188-189.

52 See the extensive correspondence of the king and Lithuanian hetman on the subject from autumn 1650., Diariusz kancelaryjny Janusza Radziwiłła, AGAD, Archiwum Radziwiłłów, dz. VI, nr 36, pp. 330-357. The king’s war intentions were also reported by the papal nuncio - see, the reports of G. de Torres to Rome, Warszawa, 8, 15 and 22 X 1650, in: Ватиканськи матеріали до історії України, t. 1 - Донесення римських нунціїв про Україну, w: Жерела до історії України, vol. 16, ed. С. Томашівський, Львів 1924 (hereinafter: С. Томашівський, Ватиканськи матеріали...), No. 169, 170, 171, pp. 92-93.

53 There is an interesting description that one can find in the hetman's letter to the king concerning the situation in which the hospodar found himself, along with his declaration of allegiance to Poland and his reguest for an indigenate: „Na to jednak narzekał [hospodar - D.M.] z wielkim żalem, że za życzliwość swoję, tak Polakom, jak też i Kozakom oświadczoną, których on w państwie swoim, sub hostilitate w państwach WKMci grassante przechowywał, et omni tractabat humanitate, bezwinnie ea hostilitate opressus. Przy tym wyrażonym żalu to subjunxit, że go ta calamitas nostri causa potkała. Bo wymawiał mu Chmielnicki: dlaczego o naszych hetmanów starał się? - czemu z więzienia powracających się humaniter excepit? - czemu pieniędzy WKMci na wojsko WKMci dodaje? - czemu z Lachami nakłada, i co się dzieje u Porty, oznajmuje? [...] Życzy sobie przecie tego, et cordicitus życzy i gorąco prosi, aby WKM pańską swą łaską dźwigać go raczył. Woli poprzysiężoną temu ejurare zdrajcy przyjaźn, a WKM in toto adhaerere, a pod skrzydłami miłościwemi WKMci orła odpoczywać, aniżeli z tym zdrajcą in ea zostawać societate. Aby ta tedy intencja nie była suspecta, prosi o indygenat, do którego otrzymania, abyś mu WKM łaską pańską dopomógł, i jeżeli już wyszła na sejmiki instrukcja, listami swemi to desiderium jego na sejmiki deferre raczył, gorącą i uniżoną za nim do Majestatu WKMci wnoszę prośbę" - M. Potocki to John Casimir, the camp near Kamienec Podolski, 22 X 1650, in: Jakuba Michałowskiego, wojskiego lubelskiego, a później kasztelana bieckiego księga pamiętnicza, z dawnego rękopisma będącego własnością Ludwika hr. Morsztyna, ed. A.Z. Helcel, Kraków 1864 (hereinafter: J. Michałowski, Księga pamiętnicza...), No. 194, pp. 577-578. 
The request of Vasile Lupu came at a good time, as the Sejm, convened for 5 December 1650 in Warsaw, had its session in the atmosphere of the approaching war with the Cossacks ${ }^{54}$. In this situation, it was convenient to attract the Moldavian hospodar to the Commonwealth. The King sent out deliberative letters to senators on this matter ${ }^{55}$. King's efforts brought the expected result because the Sejm passed the resolution on awarding the indigenate to Vasile Lupu on 24 December 1650 and ennobled his secretary, Jerzy Kutnarski. The diploma of the indigenate stressed the merits of the hospodar, who warned Poland against the danger, cooperated with the hetmans and significantly contributed to the release of numerous noblemen and the Crown Hetmans themselves from the Tatar captivity ${ }^{56}$. In view of the possibility of Cossacks' revenge, the surnames of the hospodar and his secretary were kept secret in the constitution, although they leaked to the public opinion and diplomatic circles $^{57}$. Perhaps Vasile Lupu, taught by the sad experience of Miron Barnovski, preferred not to announce the newly obtained indigenate also because of the possible repercussions in the Sublime Porte. Nevertheless, the near future seemed to confirm the rightness of the policy adopted by the hospodar to get into closer relations with Poland.

The battle of 1651 ended with the victory of the Poles and the imposition of the Biała Cerkiew agreement, more favourable to Poland, to Bohdan Khmelnytsky. Vasile Lupu triumphated and his daughter's marriage to a Cossack could be forgotten ${ }^{58}$. Unfortunately, the Cossack hetman turned out to be an expert politician and was able to wait out the failure. Since the first Sejm of 1652, which was to approve of the Biala Cerkiev agreement, was broken, Bohdan Khmelnytsky decided that the agreement was not in force. He and his army went to Moldavia to force the hospodar to implement the marriage contract. The field hetman of the Crown, Marcin Kalinowski, replacing the recently deceased Mikołaj Potocki, did not think to agree to implement the Cossacks's plans and bind Poland by connecting Moldavia with the Cossacks. He stopped the Cossacks and Tatars at Batoh by blocking the way, but through inept commanding, he led the army to the defeat and his own death. The battle fought on 1-2 June 1652 and the subsequent slaughter of Polish prisoners of war destroyed the successes of the past year and opened the way for Timofiy Khmelnytsky to the Moldavian fiancée ${ }^{59}$.

\footnotetext{
54 The king underlined the threat to the nobility in the second half of October, 1650 - see: the suplement to the instruction for the sejmiks pro d. 7 novembris, Warszawa, ok. 23 X 1650 r., in: J. Michałowski, Księga pamiętnicza..., No. 196, pp. 581-582.

55 John Casimir to the senators, Warszawa, 10 XI 1650 r., in: Документы об освободительной войне украинского народа 1648-1654 г2., еd. П.П Гудзенко, Киев 1965, №. 136, p. 355.

56 AGAD, MK 192, k. 140-140v. Druk: Diploma Indigenatus Magnifico Vasilio Palatino Moldaviae concessi, in: M. Dogiel, Codex diplomaticus Regni Poloniae et Magni Ducatus Lituaniae, vol. 1, Vilnae 1758,p. 621. See also: B. Trelińska, Album armorum..., No. 754, p. 300. The entry in the Book of Crown Metrics is so faded that it makes it virtually impossible to read the text of the diploma and the 18th century edition of M. Dogiel should be used.

57 Konstytucja ,aprobacja pewnych przywilejów” of 24 XII 1650 r., VL, vol. 4, Санкт-Петербур 1859, p. 155. Raporty dyplomatów: F. von Lisola do Ferdynanda III, Warszawa, 25 XII 1650 r., in: Жерела до історії УкраӥниРуси, wyd. М. Кордуба, vol. 12, Львів 1911 (hereinafter: М. Кордуба, Жерела...); G. de Torres do Rzymu, Warszawa, 26 XII 1650 r., in: С. Томашівський, Ватиканськи матеріали..., No. 185, p. 100. To read more on the indigenate of Vasile Lupu and Jerzy Kutnarski's ennoblement see: D. Milewski, Rywalizacja polsko-kozacka..., pp. 163-166 and idem., Jerzy Kutnarski..., pp. 119-120.

58 The enthusiasm of a hospodar for the Polish victory at Beresteczek is described by M. Costin, Latopis..., p. 193.

59 The monograph is elaborated by W.J. Długołęcki, Batoh 1652, Warszawa 1995. To read more on the political determinants of this campaign, see: D. Milewski, Rywalizacja polsko-kozacka..., pp. 175-183.
} 
In the face of a defeat of the crown army and his own military weakness, Basil Lupul could not dream of resisting the Cossacks although he was still trying to stall. Willy-nilly, he agreed to the marriage of his daughter to the son of Bohdan Khmelnytsky, which took place in Iași on 1 September 1652. Jerzy Kutnarski, the secretary of Vasile Lupu, present at the ceremony, prepared a biased record of the wedding ceremony, showing the Cossacks in the worst possible light, while the hospodar himself and his daughter were presented as innocent victims of barbarism. It was to blunt the bad impression which could arise after the Moldavian-Cossack marriage in the Commonwealth ${ }^{60}$. To justify the hospodar, we may add that he severely needed the alliance with the Cossacks at that time as he was threatened by the Tatar retaliation for organising the escape of the Polish hostages from the Crimea, left there in place of both crown hetmans. The bold and unprecedented Polish-Moldavian action, conducted in spring 1652, put the hospodar in mortal danger when the main contractor, an Armenian, Romaszkiewicz, fell into the hands of the Tatars and disclosed Jerzy Kutnarski's participation in the preparation of his mission. After Batoh, the only man who could protect the hospodar from the Tatar threat was unfortunately Bohdan Khmelnytsky ${ }^{61}$.

However one looks at it, the marriage of Rozanda Lupulówna to Timofiy Khmelnytsky did somehow associate the Moldavian hospodar with the Cossacks. Having no intention to break the relations with Poland, Vasile Lupu undertook mediation in winter 1652/1653, in which he was supported by hetman Janusz Radziwiłł, and which was aimed at achieving the Polish-Cossack agreement. The hospodar wanted to be regarded as a guarantor of peace, boasting of his alleged influence on Bohdan Khmelnytsky. Unfortunately, his expectations turned out to be vain. Neither the Poles nor the Cossacks thought about peace at that time. John Casimir pushed to a military confrontation with the 'rebels' and the Moldavian hospodar was again between the hammer and the anvil ${ }^{62}$.

Unexpectedly, the disaster came from a different direction. Close ties between Moldavia and the Cossacks worried Duke George I Rákóczi, the former ally of Bohdan Khmelnytsky and the Wallachian hospodar, Matei Basarab, his vassal and an old enemy of Vasile Lupu. Transylvania still treated Moldavia as its sphere of influence and as long as the Polish advocate, Vasile Lupu, reigned there, George I Rákóczi was associated with the Cossacks but when they could extend their sovereignty over Moldavia, he decided to avert it. Therefore, he and the Wallachian hospodar supported the conspiracy plan, organised by Gheorghe Ştefan, the logofet (chancellor) of Vasile Lupu. The indicated representative of the local boyars decided to take advantage of the dissatisfaction caused by the hospodar's policy, resulting in Moldavian defeats that started in at least 1650. Vasile Lupu got into the black books of

\footnotetext{
${ }^{60}$ Opisanie wesela Tymoszka syna Chmielnickiego z Rozanda córka Wasila Lupula hospodara wołoskiego 1652, in: Л. Гвоздик, Анонімний „Опис весілля Тимоча Хмельницького” (1652) як історичне джерело, w: Наукові записки. Збірник праць молодих вчених та аспірантів, vol. 1, Київ 1996, pp. 63-71. See also: D. Milewski, Rywalizacja polsko-kozacka..., pp. 183-189; idem., Between a Magnate and a Cossack..., pp. 58-62; E. Baidaus, War, Diplomacy, and "Family Affairs"..., pp. 49-52.

${ }^{61}$ To read more on the action of freeing the Polish hostages in spring, 1652, see: D. Milewski, Rywalizacja polskokozacka..., pp. 92-and in a popular for, idem., Ucieczka z Krymu AD 1652, „Mówią wieki”, 2011, No. 01/11 (612), pp. $40-44$

${ }^{62}$ To read more on the mediation efforts of Vasile Lupu and their fiasco see:D. Milewski, Rywalizacja polskokozacka..., pp. 190-205, and also T. Ciesielski, Sejm brzeski 1653 r. Studium z dziejów Rzeczypospolitej w latach 1652-1653, Toruń 2003, pp. 18-25 and 29-30.
} 
the local magnates by favouring Greeks and members of his own family, in whom he rightly saw faithful allies. As it turned out, they did not prevent his fall ${ }^{63}$.

The great logofet Gheorghe Ştefan, of whom Miron Costin wrote that he was 'one of those who, not having their own children, take up the thought of reigning ${ }^{964}$, belonged to the circle of trusted associates of Vasile Lupu. At the beginning of 1653, he even received a large sum of money from the hospodar, earmarked as a reserve for extraordinary accidents and was sent to Transylvania with a message, where he was to dispel the doubts concerning - by the way actual - war plans, addressed at Wallachia. Gheorghe Ştefan took advantage of the indicated circumstances to endear the Duke of Transylvania and plotted the assassination of Vasile Lupu jointly with the boyars of the Ciogolea family. The hospodar, who was to be murdered on Easter 1653, avoided the danger but had to flee to Khotyn. Meanwhile, Transylvanian and Wallachian army entered Moldavia and placed a new ruler, Gheorghe Ştefan, on the throne on 13 April $^{65}$.

Both rivals found themselves at the crossroads of their relations with the Commonwealth. Vasile Lupu, the possessor of the Polish indigenate, the Polish neighbour, meritorious for the state, crossed the border and took refuge in Kamianets Podilskyi. He had the right to think that the Poles would help him against his rival, supported by the Duke of Transylvania, hostile to the Crown. Unfortunately, the Polish army was not ready for immediate action and the Field Crown Hetman Stanisław Potocki, even advised the hospodar to seek help among the Cossacks ${ }^{66}$. He did not await the Polish advice and asked Bohdan Khmelntsky for help. Unlike the Poles, the Cossack hetman did not hesitate and did not wait. He wanted to maintain his influence in Moldavia, so, in April, he sent there corps led by Timofiy Khmelnytsky and the colonel Ivan Bohun. At the beginning of May, the Cossacks defeated the army of Gheorghe Ştefan, drove him off and occupied Iași. Following them, Vasile Lupu returned to his capital city ${ }^{67}$.

The old hospodar understood that nobody could twice enter the same river. Despite the fact that he declared friendship with the King and the Chancellor and led to a Polish-Cossack agreement $^{68}$, he soon painfully realised what his real position in Moldavia was. The Cossacks threw their way about in Iași, and the hospodar became in fact the hostage in the hands of his son-in-law. Timofiy Khmelnytsky murdered with impunity Jerzy Kutnarski, who was

\footnotetext{
63 The genesis and origins of the conspiracy are described, amongst others, by.: M. Costin, Latopis..., pp. 194-195; G. Kraus, Cronica Transilvaniei 1608-1655, ed. G. Duzinchevici, E. Reus-Mîrza, București 1965, pp. 153-154; Paweł z Aleppo, Путешествіе антіохійскаго патріарха Макарія въ Россію въ половине XVіi в., описанное его сыномъ архидіакономъ Павлом Алеппскимъ, wyd. Г. Муркос, in: Чтенія въ Иммператорскомъ обществе исторіи и древностей россійскихъ, еd. Е.В. Барсов, vol. 4, part 2, Москва 1896, pp. 86-88. See also: C. Şerban, Vasile Lupu..., pp. 195-197; P. Zahariuc, Tara Moldovei..., pp. 111-113 and D. Milewski, Rywalizacja polskokozacka..., pp. 205-213.

64 M. Costin, Latopis..., p. 194.

${ }^{65}$ The course of the conspiracy against Vasile Lupu and his overthrow are described by eyewitnesses: Paweł of Aleppo, Путешествie..., pp. 86-91 and M. Costin, Latopis..., pp. 194-200. See also: D. Milewski, Rywalizacja polsko-kozacka..., pp. 212-221.

${ }_{66}$ Bazyli Lupul do S. Potockiego, Chocim, 16 IV 1653 r., in: I. Corfus, Documente..., No. 99, pp. 166-167; S. Potocki do A. Leszczyńskiego, Busk, 2 V 1653 r., Archiwum Narodowe w Krakowie, Zbiór Pinocciego, IT, No. 363, p. 897.

67 D. Milewski, Rywalizacja polsko-kozacka ..., pp. 221-231.

68 Bazyli Lupul do Jana Kazimierza, Chocim, 4 V 1653 r., in: I. Corfus, Documente..., No. 107, pp. 175-176; id. to S. Koryciński, Chocim, 4 V 1653 r., ibid., No. 108, p. 177.
} 
a pillar of the Polish party in Moldavia, and who had just returned from the mission to the Brest Sejm ${ }^{69}$. The aforementioned fact made the worst impression in Warsaw where there was no longer any illusion about the position of Vasile Lupu in the Polish-Cossack conflict ${ }^{70}$.

In this situation, George I Rákóczi's assurances that the removal of Vasile Lupu was not an act aimed against Poland, and also an offer of alliance against the Cossacks, which Gheorghe Ştefan addressed in April, reached fertile ground ${ }^{71}$. The Polish side referred to them with restraint at first ${ }^{72}$, but the Moldavian-Cossack attack on the Wallachian region in May 1653, being in a way a retaliation for the attempt to dethrone Vasile Lupu, followed by the defeat of the invaders and the re-occupation of Moldavia by Gheorghe Ştefan and the Transylvanian-Wallachian army in July 1653, renewed the matter of Polish alliance with Transylvania and its satellites. In view of the common danger coming from the Cossacks, John Casimir concluded an Alliance with George I Rákóczi in summer, $1653^{73}$.

As a result, the Polish army soon began to cooperate with new allies on the territory of Moldavia. After the escape of Vasile Lupu to Cossacks in July 1653, Jerzy Stefan attacked the castle in Suceava, where his rival's wife with supposedly fabulous treasures took refuge. Timofiy Khmelnytsky came to the relief of the fortress in August, and he managed to push away - or rather scare away - the Moldavian-Transylvanian army from Suceava. The Cossacks were followed by the Polish corps of 4,000 led by Colonel, Jan Kondracki. He took command over the combined armies and attacked the Cossacks near Suceava. The expected victory was not achieved but it was possible to besiege the enemy. Tymofiej was killed in the battle whereas the Cossacks, deprived of hope for the arrival of relieving troops, surrendered to the sieging party on 9 October $^{74}$.

When allies were besiegingd Suczawa, the Polish army, commanded by the king himself, came near Kamianec Podilskyi, from where the Cossacks' actions were observed and the possibility of intervention in Moldavia was checked. After conquering Suceava, the allied dukes sent support troops of 4000 people to Poland, who participated in the Battle of Zhvanets (Żwaniec). No major fights took place at that time, and tiredness of Poles led them to conclude an agreement with the Tatars, who after coming to Ukraine started to act as the main ally and

\footnotetext{
${ }_{69}$ The murder was described by M. Costin, Latopis..., pp. 206-207. See also: D. Milewski, Jerzy Kutnarski..., pp. $128-130$.

70 P. Vidoni do Rzymu, Warszawa, 26 V 1653 r., in: C. Томашівський, Ватиканськи матеріали..., №. 292, pp. 173-174. See also: E. Baidaus, Politica şi diplomaţia..., p. 96.

71 Jerzy II Rakoczy do Jana Kazimierza, Feldvar, 25 III 1653 r., in: М. Кордуба, Жерела..., No. 227, p. 193; Jerzy Stefan do S. Lanckorońskiego, Jassy, 26 IV 1653 r., in: I. Corfus, Documente..., No. 104, p. 172.

72 Jan Kazimierz do Jerzego II Rakoczego, Brześć Litewski, 20 IV 1653 r., w: W.J. Rudawski, Historia polska od śmierci Władysława IV aż do pokoju oliwskiego, ed. W. Spasowicz, Petersburg 1855, pp. 224-225.

73 Jan Kazimierz do Jerzego II Rakoczego, Warszawa, 30 V 1653 r., in: Transsylvania et bellum boreo-orientale. Acta et documenta, ed. S. Szilágyi,vol. 1, Budapest 1890 (hereinafter: S. Szilágyi, Transsylvania...), pp. 259-260; a supplement to the King's instruction to J.A. Morsztyn, a deputy to Transylvania, May or June 1653, AGAD, MK, LL 33, k. 85-86. To read more on the warfare in the Wallachian region and in Moldavia in May-July, 1653, see: D. Milewski, Rywalizacja polsko-kozacka..., pp. 234-246 i T. Ciesielski, Od Batohu do Żwańca. wojna na Ukrainie, Podolu i o Mołdawię 1652-1653, Zabrze 2007, pp. 133-160.

74 To read more on the Battle of Suceava in August-October, 1653 see: D. Milewski, Wyprawa na Suczawe 1653, Zabrze 2007, pp. 79-144; id., Rywalizacja polsko-kozacka..., pp. 256-278 and T. Ciesielski, Od Batohu do Żwańca..., pp. 161-200.
} 
supporter of Cossacks. The compaign of 1653 did not bring the expected result in Ukraine and ended in failure of the Moldavian plans of Bohdan Khmelnytsky (Chmielnicki) ${ }^{75}$.

The balance of power in the Danube area changed as well. The greatest benefits were drawn by the Duke of Transylvania, who placed a hospodar, Gheorghe Ştefan, dependent on him in Moldavia. Nevertheless, a new ruler tried to maintain good relations with Poland. In 1654, in view of the fact that Bohdan Khmelnytsky had submitted Ukraine to Moscow protection, the Moldavian hospodar acted as a supporter of the Polish-Tatar agreement and tried to discredit the Cossacks in the eyes of the Turks, providing Porte with detailed information on the Cossack-Moscow alliance. ${ }^{76}$ He was the only one, among the newly acquired allies, who provided Poland with armed assistance in the fights in Ukraine. The Moldavian army supported the activities of the Crown army led by Stanisław Potocki in spring 1654 and then in winter 1655, during the joint expedition undertaken by the Poles andTatars against the Moscow-Cossack forces ${ }^{77}$. His attitude was particularly beneficial in comparison with the actions of George I Rákóczi, who in various ways avoided giving real help to Poland and even returned to contacts with Bohdan Khmelnytsky ${ }^{78}$. The only thing that the Princes of Transylvania cared about was obtaining the Polish indigenates for his sons and outstanding Transylvanian commanders, John Kemény, Stefan Petki and Franciszek Redeie. The king promised to reward them in this way for their military cooperation in 1653 and now the Duke of Transylvania ruthlessly demanded the fulfillment of the indicated promise ${ }^{79}$. Since the first Sejm of 1654 was broken, the king could not fulfill his neighbour's wish. He understood, however, that the future of the alliance with Transylvania depended on that. Therefore, before the next Sejm, in 1654, he included a recommendation to grant the indigenates to the Transylvanian, Moldavian and Wallachian hospodars in the instruction to Sejmiks ${ }^{80}$.

In this way, mainly as a result of pressure from its Transylvanian protector, whom Poland had to take into account, the newly created Moldavian hospodar was nominated for the reception of the Polish jewel of nobility, after a very short cooperation with Poland.

\footnotetext{
75 The activities under Żwaniec are described by, among others: D. Milewski, Kryzys wojskowości polskiej na przykładzie kampanii żwanieckiej Jana Kazimierza, „Barok”, 2001, R. 8, No. 15, pp. 100-107 and T. Ciesielski, Od Batohu do Żwańca..., pp. 223-270.

76 Jerzy Stefan to S. Potocki, Jassy, 9 IV 1654 r., in: I. Corfus, Documente..., No. 152, p. 233; idem. do S. Korycińskiego, Jassy, 15 IV 1653 r., ibid., No. 153, p. 235; id. to S. Potocki, Jassy, 23 VII 1654 r., ibid., No. 165, pp. 251-252.

77 D. Milewski, Polsko-mołdawska wspótpraca wojskowa przeciw Kozakom w latach 1654-1655 (Colaborarea polono-moldovenească împotriva cazacilor din anii 1654-1655), in: „Moldova între tradiţie şi actualitate”. Conferinţa ştiinţifică dedicată jubileului de 300 de ani de la înscăunarea lui Dimitrie Cantemir, ed. L. Moşanu, Ş. Levinţa, I. Codreanu, V. Constantinov, D. Braga, Chişinău 2011, pp. 123-127.

78 Jerzy II Rakoczy do Jana Kazimierza, Görgeny, 13 III 1654 r., w: Monumenta Hungariae Historica, ed. S. Szilágyi, vol. 23, Budapest 1874, No. 350, p. 292; G. Kraus, Cronica..., pp. 175-176. See also: D. Milewski, Siedmiogród i księstwa naddunajskie wobec sojuszu kozacko-moskiewskiego w 1654 r., in: Studia z dziejów stosunków Rzeczypospolitej z Państwem Moskiewskim w XVi-XVii wieku, ed. M. Nagielski, K. Bobiatyński, P. Gawron, Zabrze - Tarnowskie Góry 2013, pp. 214-218.

79 Instrukcja dla Jerzego Gillányi, posła Jerzego II Rakoczego na sejm, Alba Iulia, 1 II 1654 r., in: S. Szilágyi, Transsylvania..., pp. 296-300.

80 „Przyjaźń księcia siedmiogrodzkiego, hospodara teraźniejszego wołoskiego i multańskiego, jako z rady senatu JKM. zatrzymuje swoim dozorem, tak żądaniem swym WMciów do tego prowadzi, aby indygenat synom księcia siedmiogrodzkiego i trzem panom siedmiogrodzkim Janusza Kimeniego, Franciszka Redy, Stefana Petki obiema hospodarom były pozwolone" - instrukcja na sejmiki, Warszawa, 22 IV 1654 r., Biblioteka Polskiej Akademii Nauk w Kórniku, rkps 991, k. 501.
} 
It was a greater honour for him than for the sons of George I Rákóczi. However, unlike the Transylvanian people whose indigenates were to encourage them to further cooperation with Poland, Gheorghe Ştefan really deserved the indicated award.

The second Sejm of 1654 adopted the Transylvanian postulates and on 20 July passed the resolution on granting the indigenates to the Transylvanians and to Gheorghe Ştefan ${ }^{81}$. The relevant Diploma was entered in the Crown Register on 30 June, three days after the diplomas for the Transylvanians had been entered therein ${ }^{82}$. The diploma for Gheorghe Ştefan stressed the achievements of the hospodar for Poland made by him when he was still a great logofet, then from the period of a joint struggle with the Cossacks and Tatars, against whom he sent reinforcements to the Poles near Zhvanets, and finally the recent participation of the Moldavian army in the expedition of Stanisław Potocki to Ukraine.

The Polish indigenate was not the only reward received by the hospodar. As it had been done with Vasile Lupu, he was given consent on free trade in the Commonwealth in April 1654, which provided Gheorghe Ştefan with real financial benefits ${ }^{83}$. Everything seemed to indicate good Polish-Moldavian cooperation. Unfortunately, the catastrophe of 1655 destroyed the plans. The Commonwealth found itself on the verge of collapse and George I Rákóczi entered the ranks of its opponents by virtue of the treaty of Radnot of 6 December1656. The Transylvanian invasion of Poland in winter, 1657 included the allies of George I Rákóczi as well. The Moldavian army plundered the country on an equal footing with the Transylvanian army and tasted the final defeat together with them in July $1657^{84}$. Gheorghe Ştefan suddenly found himself in a critical situation. The action of his protector was undertaken against the interests of the Sublime Porte which had become bored with the idle observation of the growing independence of the Transylvanian vassal. The invaders were completely defeated in Podole in 1657 by the Tatars who were to be the executors of the Turkish plan to punish the unruly fiefs. The Moldavian hospodar tried to save himself by seeking help with the Great Chancellor of the Crown, whom he assured of his kindness in 1657 and to whom he presented his justification of his involvement in the invasion of Poland, hoping to endear the king $^{85}$. Nevertheless, John Casimir, who needed the help of Tatars and the friendliness of Ottomans very much at that time, did not intend to stand up for an uncertain and shaky and what is more, weak ally. Deprived of the Polish protection, the hospodar yielded to a Tatar advantage and in 1658 he lost his power in Moldavia ${ }^{86}$. He took refuge in Moldavia but was also conquerred by the Turks. The Transylvanian hegemony built by George I Rákóczi in the

\footnotetext{
${ }^{81}$ Konstytucja „Aprobacja pewnych przywilejów”, VL, vol. 4, p. 210. See also: S. Ochmann-Staniszewska, Z. Staniszewski, Sejm Rzeczypospolitej za panowania Jana Kazimierza wazy. Prawo - doktryna - praktyka, Wrocław 2000, vol. 1, p. 224.

82 Indigenatus Illustrissimo Palatino Moldaviae, AGAD, MK 195, pp. 111-114. Druk: Diploma Indigenatus Georgii Stephani Palatini Moldaviae, in: M. Dogiel, Codex diplomaticus..., vol. 1, pp. 621-623.

83 Exemptio rerum et mercium Palatini Moldaviae a theloneis et vectigalibus Regni, Warszawa, 8 IV 1654 r., AGAD, MK 195, pp. 51-52. Vasile Lupu obtained a similar one-time privilege for duty-free transport and sale of his goods in Gdansk in July 1652, and the king betrayed him, „uważając wysokie merita i nieodmienną wielką życzliwość ku nam i państwom naszym Jaśnie Wielmożnego hospodara i wojewody ziem mołdawskich" - oblata uniwersału JКМci z Warszawy, 6 VII 1652 r., ЦДІАУ, Grodzkie halickie, fond 5, op. 1, spr. 144, pp. $547-549$ (oblata w dniu 23 X 1652 r.).

${ }^{84}$ To read more on the campaign see the latest work of: M. Markowicz, Najazd Rakoczego na Polske 1657, Zabrze 2011.

85 Jerzy Stefan do S. Korycińskiego, Jassy, 13 XII 1657 r., in: I. Corfus, Documente..., No. 174, p. 266.

${ }^{86}$ M. Costin, Latopis..., pp. 234-237. Cf. P. Zahariuc, Ţara Moldovei..., pp. 367-383.
} 
Danube region collapsed. Vasile Lupu, in exile in Instanbul, was satisfied. Before his death in 1661 , the Turks placed his son, Stefanica, on the Moldavian throne, in $1659^{87}$

Summing up our considerations on the Polish-Moldavian relationship in the 17th century, perceived from the point of view of indigenates granted to hospodars, we can draw some conclusions.

The first and the most obvious fact is that Poland treated the indigenate as a form of binding a given hospodar to it and thus extending its sphere of influence to Moldavia. It was particularly evident in the case of Miron Barnovski. Granting the indigenate to Vasile Lupu was rather a form of defence and consolidation of Polish influence in Moldavia, threatened by the Cossacks. The indigenate awarded to Gheorghe Ştefan, together with the privileges for the Transylvanians, was no longer that important. The hospodar himself was clearly dependent on George II Rákóczi - as proved by the year 1657 - but he showed friendliness to Poland and did not avoid military cooperation. However, it could have been expected that in time the indigenate would tie him more strongly to Poland. As it turned out, the hopes were vain. Similarly, Vasile Lupu was not strongly attached to the Commonwealth by the Polish indigenate because when in need, he sought help among the Cossacks. Miron Barnovski showed the strongest association with Poland and he looked for shelter there. However, even he went to Moldavia in a seemingly favourable situation and did not hesitate to negotiate with the Ottomans the possibility to restore his power. Neverthelees, it is worth noting that the first two hospodars, Miron Barnovski and Vasile Lupu, tried to aquire land estates in Poland, which meant that they had more long-term plans for the country ${ }^{88}$. Both of them were also related to the magnate families in the Commonwealth, Miron Barnovski through his wife, Vasile Lupu through his son-in-law, Janusz Radziwiłł.

Another conclusion that can be drawn from the analysis concerning the history of the aforementioned three hospodars relates to a certain historical determinant defining the longterm policy of the Moldavian rulers. Squeezed between Poland and Turkey, the Moldavian hospodars had to navigate between the two indicated powers. It was impossible to maintain a policy of an unequivocal support provided to one of the parties in the long run. When Miron Barnovski did so in 1629, he was dethroned by the Turks. A similar fate happened to Gheorghe Ştefan in 1658 even though he found support in Transylvania against the Ottomans. However, the Poles managed to remove the inconvenient ruler, as evidenced by the fate of Stefan Tomșa, devoted to the Turks - he was removed from power at the request of the Polish authorities in 1623 whereby the sultan did not intend to endanger good relations with Sigismund III. The indicated situation was best understood by Vasile Lupu, who due to his skilful politics, stayed on the throne for 19 years and finally regained the Turkish grace and could witness his son's ascension to the throne in Moldavia.

And finally, the last thing - every ambitious hospodar, who wanted to count on the international arena, had to look for an alliance with Poland, sooner or later. In the then international configuration, leaving things exclusively up to the Ottomans could end in dethroning at any time, sometimes for very trivial reasons. The Turks treated hospodars

\footnotetext{
87 NN. do NN., Stambul, 8 I 1659 r., in: Documente privitóre la istoria Românilor culese de Eudoxiu de Hurmuzaki, vol. 5, part 2, Bucuresci 1886, No. XCI, p. 58. See also: D. Milewski, Rywalizacja polsko-kozacka..., p. 284.

88 Vasile Lupu tried to purchase Jazłowiec from the Crown Ensign, Aleksander Koniecpolski - see: Bazyli Lupul do Ł. Miaskowskiego, Roman, 20 I 1652 r., AGAD, A collection of paper documents, No.3974.
} 
more and more like officials who could be nominated and dismissed at their discretion, disregarding their powers as feudal rulers who had some rights to the country in which they ruled. It was clearly revealed after 1658. During the Polish-Turkish wars of 1672-1699, the Commonwealth still found supporters in Moldavia, especially at the beginning, when, for example the hospodar Stefan Petryczejko joined the Polish side in 1673. However, the deepening weakness of Poland and the invasive policy of Jan III Sobieski, trying to put his son on the Moldavian throne, gradually discouraged Moldavias, especially the hospodars, from seeking support in Warsaw ${ }^{89}$. The Polish-Turkish pacification in 1699 deprived Moldavia of its northern ally. The Moscow of Peter I, which the hospodar Dymitr Cantemir turned to in 1711, didn't meet their expectations, either. The Turks, on the other hand, completely harnessed the country, imprisoning the Greek Phanariots, associated by origin and interests with Istanbul, in Iași.

To sum up, we can say that in the 17th century, the Commonwealth was the only significant player that could be an alternative to Moldavian hospodars against the ruthless Ottoman hegemony. They understood it well, which was expressed in their efforts to obtain a Polish indigenate. Unfortunately, Poland was not able to fight openly against Turkey for influence in Moldavia and when the war started in the 70s of the 17th century, the Commonwealth first had to defend its possessions in Podolia and Ukraine and then it turned out to be too weak to reclaim Moldavia from the Turks. Nevertheless, the era of hospodars - the Polish indigenates, indicates very lively contacts between the two countries, from which Moldavian hospodars could benefit.

\section{Good neighbourhood affirmed by an indigenatus - three cases of Moldavian hospodars in 17th Century Summary}

Moldavia in modern age - especially in 16 th and 17 th centuries - being a tributary to the Ottoman Empire - still caught Polish attention. Both Poles and Turks considered Moldavia as a buffer which needed their attention. Such a situation allowed more ambitious hospodars to balance and keep as large an autonomy as it possibly could. Although Moldavian hospodars had to obey to the Porte, they often kept close diplomatic and even military relationships with Poland. Giving Polish indigenous to hospodars was a good way to keep them in obedience to Poland. This honour was given - among the others - to Miron Barnovski, Vasile Lupu and Gheorghe Ştefan. All these hospodars - although they fought against each other - saw in Poland a guarantor of their power. This article discusses the policy of these hospodars toward Poland and focuses on the circumstances of giving Polish indigenous to these rulers. The article also signals some historical principles ruling the actions of Poles, Moldavian and Turks in this difficult period.

Keywords: Moldavia, hospodars, indigenatus

About the author: dr hab. Dariusz Milewski, (a holder of a post-doctoral degree), works at the Faculty of History and Social Sciences of the Cardinal Stefan Wyszyński University in

\footnotetext{
89 The problem is analysed by I. Czamańska, Oswobodziciel czy najeźdźca? Polityka Jana III Sobieskiego wobec hospodarstw Mołdawii i Wołoszczyzny, „Roczniki Historyczne”, 1989-1990, vol. 55-56, pp. 151-177.
} 
Warsaw. He specialises in the history of modern military science and the history of modern Poland with particular emphasis on its relations with the Cossacks and the Ottoman Empire as well as its vassals. 